Article

\title{
Spatial-Temporal Patterns and Driving Forces of Ecological-Living-Production Land in Hubei Province, Central China
}

\author{
Enxiang Cai ${ }^{1,+} \mathbb{D}^{\mathbb{D}}$, Ying Jing ${ }^{1,+}$, Yaolin Liu ${ }^{1,2,3, *}$, Chaohui Yin ${ }^{1}$, Yuan Gao ${ }^{1}$ and Junqing Wei ${ }^{1}$ \\ 1 School of Resource and Environmental Science, Wuhan University, 129 Luoyu Road, Wuhan 430079, China; \\ 2015102050044@whu.edu.cn (E.C.); y.crystal@whu.edu.cn (Y.J.); 2016102050045@whu.edu.cn (C.Y.); \\ 2015102050045@whu.edu.cn (Y.G.); 2015102050047@whu.edu.cn (J.W.) \\ 2 Key Laboratory of Geographic Information System, Ministry of Education, Wuhan University, \\ 129 Luoyu Road, Wuhan 430079, China \\ 3 Collaborative Innovation Center for Geospatial Information Technology, Wuhan 430079, China \\ * Correspondence: yaolin610@163.com; Tel.: +86-27-6877-8552 \\ + These authors contributed equally to this work.
}

Received: 5 September 2017; Accepted: 27 December 2017; Published: 28 December 2017

\begin{abstract}
Ecological-living-production land (ELPL) is gaining an increasing attention of governors, planners and scholars to alleviate ecological deterioration on the premise of ensuring regional sustainable development in China. This paper has built an ecological-living-production land classification system (ELCS) by the reclassification method, and further analyzed the spatio-temporal characteristics and evolution mechanism of ELPL from 2009 to 2014 with a case study of Hubei Province of Central China. The results show that (1) land with an ecological function held a dominant role in Hubei Province. Ecological land (EL) and production-eco land (PEL) covered the largest areas. The area of EL was the largest in Western Hubei Eco-cultural Tourism Circle (WHETC), and the area of PEL accounted for the largest proportion in Wuhan Urban Circle (WUC). (2) Land with an ecological function was decreasing continuously, while the land with living function expanded rapidly. Additionally, the intensity of ELPL changes in the WUC was higher than that in the WHETC. (3) The changes of ELPL threatened the food and ecological security and adversely affected the sustainable development. The factors of population growth and GDP increase were the main driving forces of ELPL change. The results of this study provide valuable information for planning decision makings (e.g., the ELPL spatial pattern optimization).
\end{abstract}

Keywords: ecological-living-production land (ELPL); classification system; spatio-temporal pattern; driving force; Hubei Province

\section{Introduction}

The land use system is a typically comprehensive system embodying the interaction of society, economy, resources and environment, which is composed of its structure and functions $[1,2]$. The land use system bears three sub-systems: the economy, society and ecology systems [3,4]. Correspondingly, a land use system possesses three corresponding functions (i.e., production, living and ecological functions). In this sense, land can be categorized into three classes based on land mutil-functionality. That is, land with production function, land with living function and land with ecological function, namely, ecological-living-production land (ELPL). Land with production function refers to the land for agricultural, industrial and commercial activities to yield physical supply (e.g., crops and industrial products). Land with living function refers to the spatial carrier for people's livelihood (e.g., residential areas). Land with ecological function refers to land for ensuring ecological security (e.g., 
forest and lakes). The ecological function is the foundation of two other land functions (i.e., living and production functions). Broadly speaking, maintaining land ecological function is the key to realize the harmony between human development and sustainable land use [5].

Land use function refers to the private and public products and services provided by different land use patterns, while land multi-functionality is described as land's economic, social and ecological functions [6]. Studying the land multi-functionality enables land use researchers to shift from focusing on land use pattern to concentrating on the conversion of land with different functions $[7,8]$. The notion of land use multi-functionality is rooted in the concepts involving agriculture, ecosystem productions and services, and landscape functions $[9,10]$. The previous studies on land multi-functionality have yielded abundant theoretical results on the function identification, land functional categorization $[6,11,12]$, and function evaluation $[6,13,14]$. However, the empirical cases concerning land use multi-functionality on land use management are still rare, especially in China, where a tense man-land relationship occurs due to rapid economic development. The space-oriented plans or regulations involving the multifunctional land (i.e., ecological land, living land and production land) have been introduced in China during these recent years $[15,16]$. Consequently, it is of great practical significance to establish a feasible ecological-living-production land classification system (ELCS) and evaluation method to guide the scientific management and sustainable land use in China.

China is experiencing a rapid process of industrialization, urbanization and economic development in the context of the Reform and Opening-up Policy. However, due to the large population and inadequate land resources supplies, the competition between various lands is becoming increasingly fierce. Taking certain types of land, for example, a large amount of cultivated land has been occupied by the construction land due to constant urban expansion [17-19]. Likewise, forest land and water body have been occupied by cultivated land for food production [20,21], and the slope farmland converted to forest and grassland owing to ecological restoration [22,23]. The land use competition actually refers to the conflicts and compromises between land with different functions and relevant underlying objectives $[24,25]$. The conflicts among various types of land have restricted China's social and economic development [26,27]. Given that China is still a developing country, the conflicts between various types of land are argued to last in the next few decades. Multifunctional land use is an important path to solving these conflicts by coordinating social and economic development and promoting efficient and sustainable land use [28,29].

Western, developed countries encountered the same predicament as China in the course of industrialization and urbanization, and they adopted the development strategy of optimizing the territory space through emphasizing environmental protection [30-32]. The experience of western countries is of great significance to the development of China. The report of 18th National Congress of the Communist Party of China has proposed the goal and the principle of the national territory optimization based on the ELPL; in other words, the spatial governance of ELPL has become an important section of land management in China [5]. ELPL has been gaining increasing attention of governors, planners and scholars for alleviating ecological deterioration in the premise of ensuring regional sustainable development. The Outline of the National General Land-Use Planning (2006-2020) issued by China's State Council puts forward the guidance to control the expansion of production land, guarantees the supply of living land and increases the proportion of ecological land [15]. In recent years, the scholars have performed a great deal of studies on ELPL, including on the theoretical framework construction $[33,34]$, the classification $[6,34,35]$, the quantitative recognition of ecological, living and production function [35] and the spatial optimization [36-38]. Understanding the spatio-temporal pattern and evolution mechanism of ELPL is the basis for ELP planning and the optimization of decision making. However, there is still a lack of research to fill this gap. The land management in China is mainly based on the official land use data and extant land classification standards [39,40]. Most of the established ELCSs are complex and lack the connection with the existing land use classification, which is infeasible to guide the ELPL management. How to link up the ELCS with the existing national 
land classification standards is the practical demand of constructing the ELPL spatial pattern and strengthening the ELPL management.

Hubei Province features a flat eastern part with concentrated population and developed economy, and a mountainous western part with most undeveloped rural areas. The natural and economic differences between east and west in Hubei Province are similar to those of China. Accordingly, Hubei Province is deemed as a representative area to study land use and economic issues in China. This study is implemented with a specific focus on Hubei Province of Central China as the research area and analysis the ELPL change and its driving forces. First, we built an ELPL classification system by the reclassification method. Second, the spatio-temporal pattern of ELPL was characterized. Third, we analyzed the dynamic change of ELPL from 2009 to 2014 and explored the driving forces by the canonical correlation analysis (CCA) method. The research makes up for the lack of studying the ELPL spatio-temporal evolution mechanism and provides implications for the spatial planning and decision-making to coordinate man-land relationship.

\section{Materials and Methods}

\subsection{Study Area}

Hubei Province is located in the middle reaches of the Yangtze River in Central China $\left(29^{\circ} 05^{\prime}-33^{\circ} 20^{\prime} \mathrm{N}\right.$ and $\left.108^{\circ} 21^{\prime}-116^{\circ} 07^{\prime} \mathrm{E}\right)$ with an area of $185,900 \mathrm{~km}^{2}$ and a varied topography (higher in the west and east and lower in the middle) consisting of mountains, hills, basins and plains, etc. The western part of Hubei Province is a high-elevation mountain area and the northeast and southeast part are hilly areas. In the middle part is the flat Jianghan Plain (i.e., the alluvial area of Yangtze River and Han River), which is an important food production area (Figure 1). In 2015, Hubei Province's GDP was 2955.02 billion RMB with the population of 58.52 million, as well as the urbanization rate $56.7 \%$. According to the Development Strategy of Two Circles and One Zone proposed by the Hubei Provincial Government in 2010 to realize integrated and sustainable development, Hubei Province is partitioned into Wuhan Urban Circle (WUC) and Western Hubei Eco-cultural Tourism Circle (WHETC). WUC is the important advanced manufacturing and high-tech industrial base, modern servicing center and integrated transportation hub in China. WHETC is the ecological green-shelter of the Central and Southern China and the water supply resource of the middle route of the South-to-North Water Transfer Project. In 2015, the area, population and GDP accounted for $31 \%, 53 \%, 60 \%$ in WUC and $69 \%, 47 \%, 40 \%$ in WHETC respectively.

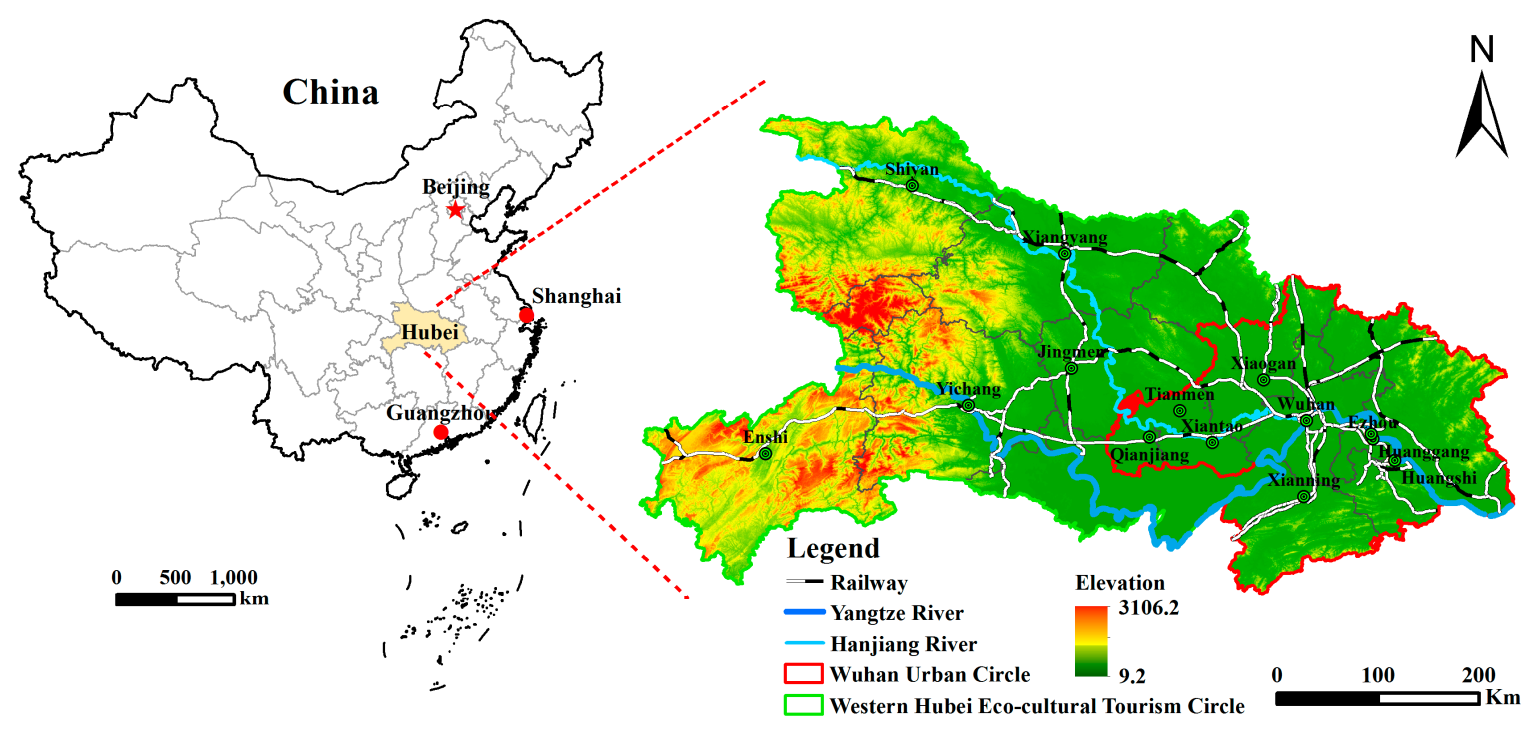

Figure 1. Location, administrative divisions, and elevation of Hubei Province. 


\subsection{Data Sources}

The land use data are obtained from land use cover vector data at 1:10,000 scale, derived from the Second National Land Survey (SNLS) in 2009 and the Annual Land Use Change Survey (ALUCS) in 2014. The SNLS began in 2007 and completed in 2009, as a national territory surveying project organized by the State Council. The land use data obtained from SNLS is characterized by its large quantity, wide coverage and high accuracy on a basis of advanced technologies and management techniques. In order to collect land use information yearly, based on the SNLS data, the ALUCS has been carried out since 2010 to update the data of SNLS annually. Thenceforth, a series of official, accurate and comprehensive digital data reflecting the situation of land use in China has been formed. DEM data are collected from the advanced spaceborne thermal emission and reflection radiometer global digital elevation model provided by NASA for free (ASTERGDEM, http://gdem.ersdac.jspacesystems.or.jp/).

According to Heilig (1997) [41], five socioeconomic forces are selected to be the major drivers of land use change in China: population growth, urbanization, industrialization, changes in lifestyles and consumption modes, and the shifts of political and economic arrangements and institutions. This paper adopted the socioeconomic forces from the abovementioned five aspects and used the SPSS 24 software (IBM, Amon, NY, USA) to analyze the driving forces on ELPL change. The selected influencing forces are urbanization rate (UR), population (Pop), GDP, the primary industry output (PI), the second industry output (SI), the tertiary industry output (TI), fixed assets investment (FAI), retail sales (RS), fiscal revenue (FR), urban residents' income (URI), and rural residents' income (RRI). The socioeconomic data in this study are from the Statistical Yearbook of Hubei Province (2010 and 2015) and the Statistical Yearbook of various cities in Hubei Province (2010 and 2015) [42,43].

\subsection{ELPL Quantifying Spatial Pattern Change}

\subsubsection{Land Use Transfer Matrix}

The land use transfer matrix reflects the transformation of the research area during one certain period. This is used to describe the changing direction of various land use types and the origin and composition of land use types at the end of the study period [44]. The variables in the transfer matrix can be the areas of land use type. The transfer probability matrix of regional land use change can also be generated to infer the trend of regional land use change under some specific scenarios. The mathematical form is

$$
S_{i j}=\left[\begin{array}{ccccc}
S_{11} & S_{12} & S_{13} & \cdots & S_{1 n} \\
S_{21} & S_{12} & S_{21} & \cdots & S_{2 n} \\
S_{31} & S_{32} & S_{31} & \cdots & S_{3 n} \\
\vdots & \vdots & \vdots & \vdots & \vdots \\
S_{n 1} & S_{n 2} & S_{n 1} & \cdots & S_{n n}
\end{array}\right]
$$

where $S$ is the area of the land, $n$ is the number of ELPL types, $i$ and $j$ are the ELPL types at the beginning and the end of the study period.

\subsubsection{Pearson Correlation Coefficient}

The Pearson correlation coefficient is employed to present the linear relationship between two random variables. Historically, it is the first formal correlation measure and it is still one of the most widely-used relation measures [45]. The Pearson correlation coefficient of two variables $X$ (socioeconomic forces, such as UR, PU, GDP, STI, etc.) and Y (ELPL changes, such as EL, EPL, PEL, LL, PLL, PL) is formally defined as the covariance of the two variables divided by the product of their standard deviations. The formula is Equation (2):

$$
\mathrm{r}_{x y}=\frac{\sum\left(x_{i}-\bar{x}\right) \sum\left(y_{i}-\bar{y}\right)}{\sqrt{\left(x_{i}-\bar{x}\right)^{2}} \sqrt{\left(y_{i}-\bar{y}\right)^{2}}}
$$


where $\bar{x}=\frac{1}{n} \sum_{i=1}^{n} x_{i}$ denotes the mean of $x \cdot \bar{y}=\frac{1}{m} \sum_{i=1}^{m} y_{i}$ denotes the mean of $y$. The coefficient $\mathrm{r}_{x y}$ ranges from -1 to 1 and it is invariant to linear transformations of either variables. The sign of the correlation coefficient is positive if the variables are directly related and otherwise negative if they are inversely related. If $\mathrm{r}_{x y}=0$, then $x$ and $y$ are deemed to be uncorrelated. The closer the value of $\left|\mathrm{r}_{x y}\right|$ is to 1 , the stronger the measures are close to a linear relationship. This is because the association measure reflects the tendency of changes for each pair of corresponding expression levels in the two profiles.

\subsubsection{Canonical Correlation Analysis}

In this paper, the CCA method was used to quantify the socioeconomic forces of ELPL change in Hubei Province. CCA was introduced by H. Hotelling in 1936 and became a relatively complete theory in the 1970s. As a method to analyze the causal relationship between two sets of variables, CCA maximizes the correlation between two sets of variables by exploring their optimum linear combination. In this study, two sets of ELPL change variables and socioeconomic factors were used to establish two canonical equations as follows:

$$
\begin{gathered}
\chi_{1}=\alpha_{11} X_{1}+\alpha_{12} X_{2}+\ldots+\alpha_{1 p} X_{p} \\
\eta_{1}=\beta_{11} Y_{1}+\beta_{12} Y_{2}+\ldots+\beta_{1 q} Y_{q}
\end{gathered}
$$

where $\chi_{1}$ is a linear combination of variants representing ELPL change variables, $\eta_{1}$ is another linear combination of variants representing socioeconomic variables. The purpose of canonical linear correlation is to maximize the correlation of the two linear combinations $\left(R_{c}\right)$ by estimating the weighting coefficients $\left(\alpha_{11}, \alpha_{12}, \ldots, \alpha_{1 p} ; \beta_{11}, \beta_{12}, \ldots, \beta_{1 q}\right)$ of the above equations. By repeating these steps, several groups of canonical equations can be obtained, and the canonical correlation between each group of canonical equations shows a decreasing trend. The formula is Equation (4):

$$
R_{c}=\frac{E\left[U V^{T}\right]}{\sqrt{E\left[U^{2}\right] E\left[V^{2}\right]}}=\frac{E\left[\alpha^{T} x y^{T} \beta\right]}{\sqrt{E\left[\alpha^{T} S_{x x} \alpha\right] E\left[\beta^{T} S_{y y} \beta\right]}}=\frac{\alpha^{T} S_{x y} \beta}{\sqrt{\alpha^{T} S_{x x} \alpha \times \beta^{T} S_{y y} \beta}}
$$

where $E$ is the mathematical expectation of canonical variables, $S_{x x}$ is the covariance matrix of variable set $X, S_{y y}$ is the covariance matrix of variable set $Y, S_{x y}$ is the cross-covariance matrix of the variable set $X$ and set $Y$.

\subsection{Ecological-Living-Production Land Classification System}

The government's land management is mainly based on official land use data and the existing land classification standards. The national standards of land classification in China mainly include the Current Land Use Condition Classification (GB/T21010-2007) [40] and the Classification of City Land Use and Standard of Land Use Planning and Construction Land (GB50137-2011) [39]. As national standards, the pre-existing cover classes mentioned above are of great significance for the land use research and management. However, this classification primarily concerns land with the production and living function, losing sight of land ecological function. Specifically, the classification system identified certain types of land (marshland, idle land, bare land, etc.) with important ecological value as unused land. This classification is susceptible to make local government officials arbitrarily convert the "unused land" to agricultural land or construction land owing to immediate benefits [35]. On the basis of the ELPL theory and the criteria of the major functions of land-use types from ecological perspective, the land was reclassified into six categories: ecological land (EL), eco-production land (EPL), living land (LL), production-eco land (PEL) and production land (PL) (Table 1). For example, arid land and paddy field in the pre-existing cover classes are the land use types of cultivated land mainly used to produce wheat and rice for grain production, but they also have certain ecological value as vegetation landscape. Therefore, they are classified as PEL. 
Table 1. Ecological-living-production land classification system.

\begin{tabular}{|c|c|c|}
\hline Class & Land Use Types & Illustration \\
\hline Ecological land & $\begin{array}{l}\text { Forest land, shrub forest, unused } \\
\text { woodland, unused grassland, } \\
\text { rivers, lakes, coastal beach, inland } \\
\text { beach, glaciers and snow, idle } \\
\text { land, saline land, marshland, } \\
\text { sandy land, bare land, sightseeing } \\
\text { and special land }\end{array}$ & $\begin{array}{l}\text { Land with the function of water and } \\
\text { soil conservation, sand fixation, flood } \\
\text { regulation, riparian protection and } \\
\text { biodiversity conservation. } \\
\text { The land that can conserve the } \\
\text { degraded land (such as saline land, } \\
\text { marsh, etc.) has important ecological } \\
\text { value and is also designated as } \\
\text { ecological land. }\end{array}$ \\
\hline Eco-production land & $\begin{array}{l}\text { Natural grassland, artificial } \\
\text { grassland, reservoir, pond }\end{array}$ & $\begin{array}{l}\forall \text { Land with dual functions of ecology } \\
\text { and production, but its ecological } \\
\text { function is stronger than that } \\
\text { of production }\end{array}$ \\
\hline Living land & Urban, towns, villages & $\begin{array}{l}\diamond \text { The land where people live, including } \\
\text { urban living land and rural } \\
\text { living land }\end{array}$ \\
\hline Production-eco land & $\begin{array}{l}\text { Arid land, paddy field, irrigated } \\
\text { land, orchard, tea garden, } \\
\text { other gardens }\end{array}$ & $\begin{array}{l}\text { The land has a strong production } \\
\text { function, is the cornerstone of } \\
\text { safeguarding national food security, } \\
\text { but also has some ecological functions. }\end{array}$ \\
\hline Production-living land & $\begin{array}{l}\text { Railway land, highway land, rural } \\
\text { road, airport land, port land, } \\
\text { pipeline transport land }\end{array}$ & $\begin{array}{l}\leftrightarrow \text { The land has the dual function of } \\
\text { production and living, and it is } \\
\text { difficult to distinguish in space, so it is } \\
\text { classified as production-living land. }\end{array}$ \\
\hline Production land & $\begin{array}{l}\text { Ditches, hydraulic construction } \\
\text { land, agricultural facility land, } \\
\text { field ridge land, mining land }\end{array}$ & $\begin{array}{l}\leftrightarrow \text { Land used for agriculture or } \\
\text { industrial production facilities }\end{array}$ \\
\hline
\end{tabular}

This classification method realizes an effective connection between the ELPL classification system and the existing land use classification standards, provides a reference for the feasibility of ELPL planning and management for the land management departments.

\section{Results}

\subsection{The ELPL Spatial-Temporal Pattern}

There were obvious differences in the areas of various functional land. The proportion of the land with ecological function was the largest, while the proportion of the land with living and production function was the smallest. Specifically, EL and PEL covered the top two largest land areas with the respective $989,269.35$ ha and $982,389.97$ ha, accounting for $52.82 \%$ and $33.45 \%$ of the total area of Hubei Province in 2014; the area of LL and EPL were 124,017.74 ha and 98,585.22 ha, accounting for 6.67\% and $5.30 \%$; PLL and PL were the two smallest, respectively accounting for $0.48 \%$ and $1.28 \%$ (Table 2).

The proportions of ELPL in WUC and WHETC were not the same. The largest proportion of ELPL in WHETC was EL, while that in the WUC was PEL. WUC is more socially and economically developed than WHETC, and with a flat terrain. The proportion of land with living and production function (i.e., PLL, LL, PEL and PL) in WUC was significantly higher than that in WHETC. The WHETC has higher altitude, and its mountain area is larger. The proportion of land with ecological function was larger than that in WUC. 
Table 2. The areas of ecological-living-production land in Hubei Province in 2014. WUC: Wuhan city circle; WHETC: Western Hubei Eco-Cultural Tourism Circle. Unit: ha, \%.

\begin{tabular}{ccccccc}
\hline \multirow{2}{*}{ Region } & $\begin{array}{c}\text { Ecological } \\
\text { Land }\end{array}$ & $\begin{array}{c}\text { Eco-Production } \\
\text { Land }\end{array}$ & $\begin{array}{c}\text { Production-Eco } \\
\text { Land }\end{array}$ & Living Land & $\begin{array}{c}\text { Production-Living } \\
\text { Land }\end{array}$ & $\begin{array}{c}\text { Production } \\
\text { Land }\end{array}$ \\
\hline Hubei & $982,389.97$ & $98,585.22$ & $622,129.55$ & $124,017.74$ & 8874.40 & $23,712.59$ \\
Province & 52.82 & 5.30 & 33.45 & 6.67 & 0.48 & 1.28 \\
\hline \multirow{2}{*}{ WUC } & $221,404.69$ & $46,701.71$ & $236,826.29$ & $57,848.09$ & 4927.72 & $12,066.66$ \\
& 38.19 & 8.06 & 40.85 & 9.98 & 0.85 & 2.08 \\
\hline \multirow{2}{*}{ WHETC } & $760,985.29$ & $51,883.51$ & $385,303.26$ & $66,169.65$ & 3946.68 & $11,645.92$ \\
& 59.46 & 4.05 & 30.10 & 5.17 & 0.31 & 0.91 \\
\hline
\end{tabular}

The ELPL spatial distribution patterns in Hubei Province are similar in 2009 and 2014 (Figure 2). EL was mainly distributed in mountainous areas in the western and the hilly areas in the northeastern and southeastern. PEL was concentrated in the Jianghan Plain in the central part of Hubei Province. The area of Jianghan Plain is flat and rich in water resources. This plain has been reclaimed as the main grain producing area for a long time. LL mainly refers to urban and rural settlements, and its distribution was basically consistent with the location of the cities in Hubei Province and characterized by the concentration in the WUC and dispersed in the WHETC. The distribution of EPL, PL and PLL were less distributed and fragmented.

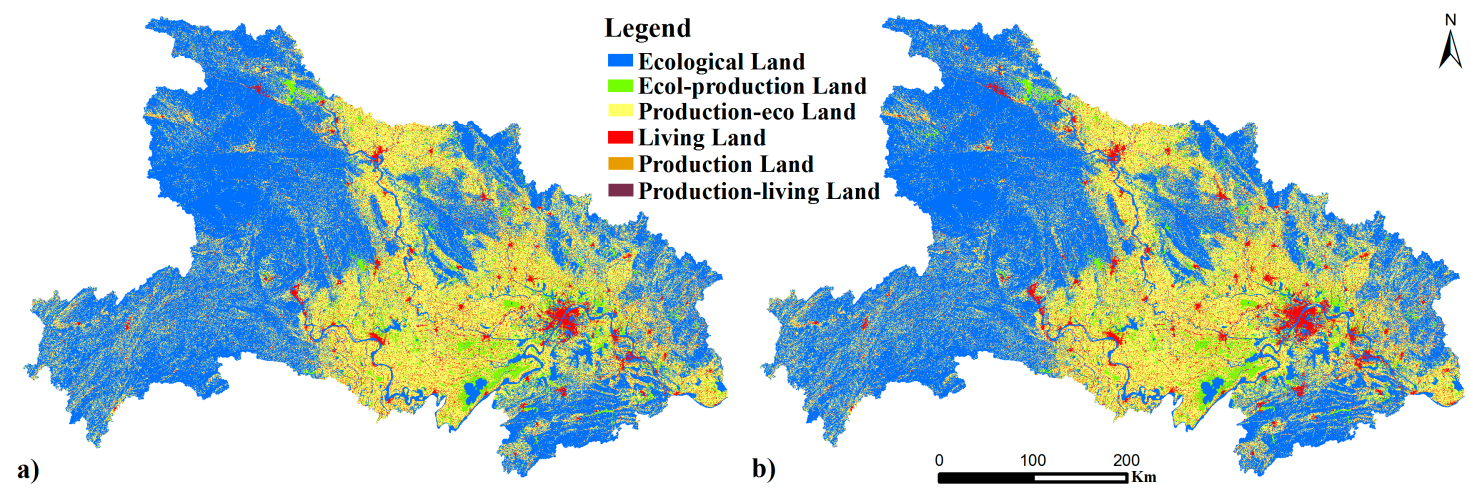

Figure 2. Spatial pattern of ecological-living-production land in Hubei Province. (a) 2009; (b) 2014.

\subsection{ELPL Structural Changes}

The changes of ELPL characteristics in Hubei Province from 2009 to 2014 were: the areas of EL, EPL and PEL were decreased and the areas of LL, PLL and PL were increased. This indicates that the land with the living and production function continues to erode the land with the ecological function. The specific performances were as followings (shown in Table 3):

(1) The area of EL decreased greatly from 2009 to 2014, reaching 6879.37 ha. In the WUC, the area of EL reduced by 2989.08 ha, which was mainly occupied by LL and PEL. In the WHETC, EL was mainly transformed into PEL of 2237.62 ha, and the expansion of LL also occupied a large amount of EL.

(2) The area of EPL was reduced by 1473.91 ha, of which 1397.12 ha reduced in the WUC and the rest reduced in the WHETC. The reduction of EPL in Hubei Province was mainly occupied by LL. The EPL has been occupied by LL for 1041.96 ha in the WUC, and the amount was 409.09 ha in the WHETC. Being occupied by PEL and PLL were also the main reasons for the EPL loss in the WHETC.

(3) The amount of PEL was reduced by 7106.34 ha, including 4080.13 ha in the WUC reduced and 3026.22 ha in the WHETC. The reduction of PEL was mainly occupied by LL in WUC. In the WHETC, there was 1116.36 ha of PEL converted into EL. 
(4) The area of LL had the largest increase of 11,674.84 ha in Hubei Province. The increment of LL area was 6629.30 ha in the WUC, and 5045.52 ha in the WHETC. The expansion of LL mainly encroached on PEL and EL.

(5) The proportion of PLL and PL in the ELPL was small. However, the demand for PLL and PL has been increasing continuously to ensure the social-economic development. The PLL and PL in Hubei Province have increased by 2759.59 ha and 992.58 ha respectively. The main sources of the increment of PLL and PL were PEL and EL.

Table 3. Conversion matrix for the ecological-living-production land of Hubei Province. EPL: Eco-production Land; EL: Ecological Land; LL: Living Land; PEL: Production-eco Land; PLL: Production-living Land; PL: Production Land; WUC: Wuhan city circle; WHETC: Western Hubei Eco-Cultural Tourism Circle. Unit: ha.

\begin{tabular}{cccccccccc}
\hline Region & Land Types & EL & EPL & PEL & LL & PLL & PL & Gross Loss & Changes \\
\hline \multirow{6}{*}{ Hubei } & EL & - & 436.90 & 5283.07 & 2094.14 & 701.03 & 373.13 & 8888.27 & -6881.76 \\
& EPL & 67.13 & - & 484.48 & 1451.05 & 287.78 & 100.15 & 2390.59 & -1473.93 \\
Province & PEL & 1706.07 & 408.13 & - & 9051.40 & 1748.71 & 854.96 & $13,769.28$ & -7106.81 \\
& LL & 189.61 & 57.91 & 714.23 & - & 143.69 & 51.97 & 1157.41 & $11,674.49$ \\
& PLL & 5.20 & 2.02 & 10.26 & 17.61 & - & 93.12 & 128.20 & 2795.60 \\
& PL & 38.50 & 11.70 & 170.43 & 217.70 & 42.59 & - & 480.92 & 992.40 \\
& Gros gain & 2006.51 & 916.66 & 6662.47 & $12,831.90$ & 2923.80 & 1473.32 & & \\
\hline \multirow{6}{*}{ WUC } & EL & - & 32.73 & 2237.62 & 1014.30 & 274.71 & 182.37 & 3741.73 & -2991.94 \\
& EPL & 52.38 & - & 268.57 & 1041.96 & 199.05 & 46.49 & 1608.46 & -1397.08 \\
& PEL & 589.72 & 158.27 & - & 4980.67 & 884.83 & 427.26 & 7040.74 & -4080.31 \\
& LL & 83.96 & 14.76 & 345.71 & - & 61.59 & 34.51 & 540.53 & 6629.17 \\
& PLL & 1.90 & 1.28 & 4.97 & 9.64 & - & 0.72 & 18.51 & 1431.55 \\
& PL & 21.84 & 4.34 & 103.55 & 123.13 & 29.88 & - & 282.74 & 408.61 \\
& Gros gain & 749.79 & 211.38 & 2960.43 & 7169.70 & 1450.06 & 691.35 & & \\
\hline \multirow{6}{*}{ WHETC } & EL & - & 404.17 & 3045.44 & 1079.84 & 426.32 & 190.76 & 5146.54 & -3889.82 \\
& EPL & 14.75 & - & 215.91 & 409.09 & 88.73 & 53.66 & 782.13 & -76.85 \\
& PEL & 1116.36 & 249.86 & - & 4070.73 & 863.88 & 427.70 & 6728.53 & -3026.13 \\
& LL & 105.65 & 43.15 & 368.52 & - & 82.10 & 17.46 & 616.88 & 5045.32 \\
& PLL & 3.30 & 0.74 & 5.29 & 7.96 & - & 92.40 & 109.69 & 1364.05 \\
& PL & 16.67 & 7.36 & 66.88 & 94.57 & 12.71 & - & 198.18 & 583.61 \\
& Gros gain & 1256.72 & 705.28 & 3702.04 & 5662.20 & 1473.74 & 781.97 & & \\
\hline
\end{tabular}

\subsection{Driving Forces Analysis of the ELPL Changes}

\subsubsection{The Natural Factors}

The natural forces that affect land use change include precipitation, climate, hydrology, topography, etc. Most of the natural forces have little influence on land use change in the short term, but the terrain forces have a great influence on the spatial changes of land use. In this study, we selected the two terrain factors: slope and aspect to analyze the natural driving forces of ecological-living-production land change. As shown in Figure 3, the terrain slope has an obvious influence on the change of ELPL. The amount of changed ELPL decreases as the terrain slope increases. The change of ELPL mainly occurred in the gentle slope areas $\left(\leq 5^{\circ}\right.$ and $\left.5-15^{\circ}\right)$. In the steep slope areas $\left(>15^{\circ}\right)$, the ELPL changed less. However, the performance of each type of ELPE was different with the slope increasing. In steep slope areas $\left(>15^{\circ}\right)$, the lost natural land (i.e., EL and EPL) was significantly greater than the gained, while the change of artificial land (i.e., PEL, LL, PL and PLL) was the opposite. It indicates that human production and living activities began to expand in high slope areas, and occupied a great deal of ecological land. 


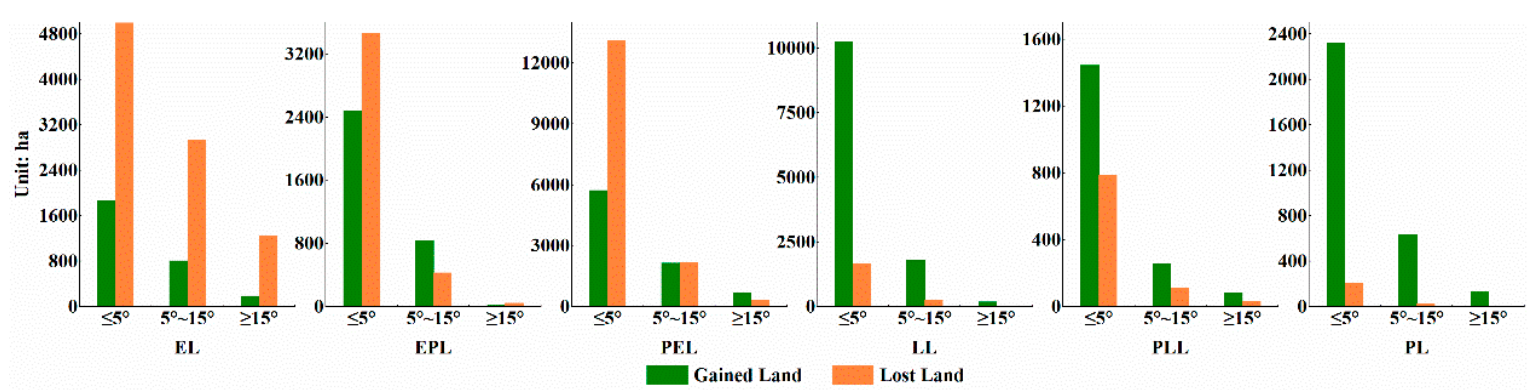

Figure 3. Slope classification and ecological-living-production land areas change. EPL: Eco-production land; EL: ecological land; LL: living Land; PEL: production-eco land; PLL: production-living land; PL: production land.

According to the effect of terrain aspect on soil moisture and sunlight, the terrain aspect is divided into five categories: flat side, sunnyside, semi-sunnyside, shadyside and semi-shadyside [37]. The production and living conditions in the area of sunnyside and semi-sunnyside are better than that in the area of shadyside and semi-shadyside. As shown in Figure 4, the lost land of EL mainly occurred in the shadyside while that of PEL and EPL mainly occurred in the sunnyside. The gained land of LL, PLL and PL in the area of sunnyside was more than that in the area of shadyside. It should be noted that a large amount of land with the ecological function was occupied by the land with living and production function in the areas with better natural conditions, which has adverse effects on ecological and food security.
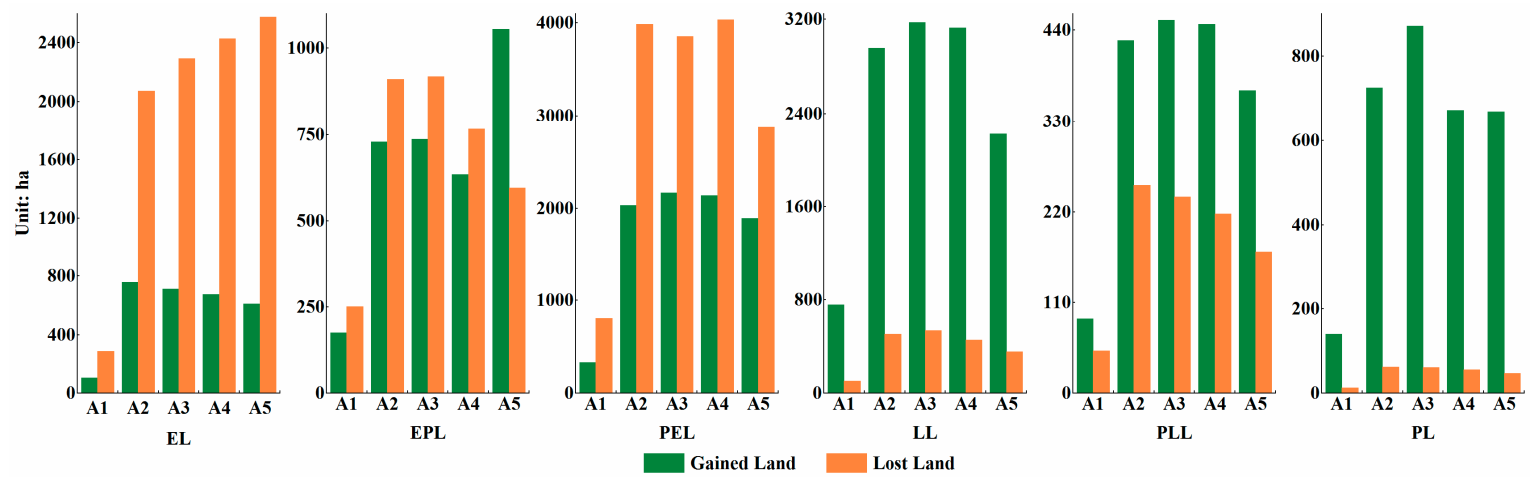

Figure 4. Aspect classification and ecological-living-production area change. A1: Flat slope $\left(0^{\circ}\right)$; A2: sunnyside $\left(135-225^{\circ}\right)$; A3: semi-sunnyside $\left(90-135^{\circ}, 225-270^{\circ}\right)$; A4: shady side $\left(45-90^{\circ}, 270-315^{\circ}\right)$; A5: semi-shady side $\left(0-45^{\circ}, 315-360^{\circ}\right)$; EPL: eco-production land; EL: ecological land; LL: living land; PEL: production-eco land; PLL: production-living land; PL: production land.

\subsubsection{Socioeconomic Factors}

First, the Pearson correlation coefficients were used to analyze the relationship between ELPL change and socioeconomic factors. We used $1 \%$ and $5 \%$, respectively, as the confidence intervals for the significant correlation analysis. As shown in Table 4, the factors (e.g., GDP, Pop, FAI, FR, RS, URI and RRI) were significantly correlated with the change of ELPL. These factors were significantly positively correlated with the change of LL and PLL but negatively correlated with the change of EPL and PEL. Referring to the study of Pradhan et al. (2017) to analyze the sustainable development goal (SDG) interactions [46,47], the positive and negative correlations between socioeconomic factors and the changes of ELPL can be classified as synergy and trade-off. The economic development and the increase of population, consumption, fiscal revenue, investment and income have a synergetic relationship with the increasing of LL and PLL, whereas trade-offs relationship with EPL and PEL. 
Table 4. The social-economic driving factors correlation degree of ecological-living-production changes. EPL: eco-production land; EL: ecological land; LL: living land; PEL: production-eco land; PLL: production-living land; PL: production land; UR: urbanization rate; Pop: population; PI: the primary industry output; SI: the second industry output; TI: the tertiary industry output; FAI: fixed assets investment; RS: retail sales; FR: fiscal revenue; URI: urban residents' income; RRI: rural residents' income.

\begin{tabular}{ccccccc}
\hline Factors & EPL & EL & LL & PEL & PLL & PL \\
\hline GDP & $-0.506^{* *}$ & -0.057 & $0.727^{* *}$ & -0.573 & 0.441 & -0.089 \\
Pop & $-0.427^{* *}$ & -0.019 & $0.639^{* *}$ & -0.507 & 0.309 & -0.14 \\
UR & $0.088^{*}$ & 0.022 & $-0.251^{*}$ & $0.232^{*}$ & -0.106 & 0.015 \\
PI & 0.011 & $-0.28^{* *}$ & 0.109 & 0.115 & -0.072 & -0.194 \\
SI & -0.081 & 0.149 & 0.105 & $-0.231^{*}$ & 0.157 & 0.146 \\
TI & 0.06 & 0.067 & -0.197 & $0.165^{* *}$ & -0.115 & -0.021 \\
FAI & -0.537 & -0.041 & $0.733^{* *}$ & $-0.596^{* *}$ & $0.529^{* *}$ & -0.085 \\
FR & $-0.48^{* *}$ & 0.001 & $0.637^{* *}$ & $-0.512^{* *}$ & $0.396^{* *}$ & -0.131 \\
RS & $-0.471^{* *}$ & -0.023 & $0.588^{* *}$ & $-0.43^{* *}$ & $0.319^{* *}$ & -0.124 \\
URI & $-0.343^{* *}$ & 0.089 & $0.435^{* *}$ & $-0.416^{* *}$ & $0.305^{* *}$ & -0.057 \\
RRI & $-0.53^{* *}$ & 0.148 & $0.546^{* *}$ & $-0.518^{* *}$ & $0.434^{* *}$ & 0.012 \\
\hline
\end{tabular}

Note: ${ }^{* *}$ Significant at the $1 \%$ level; ${ }^{*}$ Significant at the $5 \%$ level.

To be more specific concerning the particular regions and the tensions between the eastern (WUC) and western (WHETC) areas, this paper analyzed the socio-economic driving factors of ELPL change in WUC and WHETC through CCA method. The results of CCA were shown in Table 5. The sample covariance of the canonical variables within the same variable set was zero, and the sample covariance of the canonical variables that do not correspond to different variable set was also zero. Therefore, the analysis of the relationship between the variable set $Y$ (ELPL changes) and the variable set $X$ (socioeconomic forces) involves only the analysis of the canonical variables extracted from the two variable sets [38]. The canonical correlations of canonical variable 1 and variable 2 of WUC and WHETC were $0.963,0.878$ and $0.917,0.782$, respectively. The significance indexes of these variables were below 0.05 . The explanatory variables identified by these variables can adequately explain the distribution of the corresponding standard variables. The explanatory information for the other canonical variables was not sufficient and was not discussed.

From the canonical loading of ELPL change in WUC, we first extracted the changes variable of EPL and LL form the variable set $Y$ in the canonical variable 1, their canonical loadings were -0.916 and 0.807. The corresponding explanatory variables were FAI, GDP, FR, RS and Pop (the canonical loadings are $0.926,0.906,0.872,0.867$ and 0.812 ) in the variable set $X$. It indicates that the growth of GDP, population and the increase of fixed asset investment, fiscal revenue and retail sales were beneficial to the expansion of LL and led to the decrease of PEL in WUC. Secondly, we extracted the changes variable of PEL from the variable set $Y$ in the canonical variable 2 . The canonical loading was 0.797. The corresponding explanatory variable was the primary industry and second industry output, and their canonical loading were 0.652 and -0.594 . The development of agriculture was positively related to the increase of PEL, while the development of the second industry caused the decrease of PEL in WUC.

From the canonical loading of ELPL change in WHETC, we first extracted the changes variable of LL from the variable set $Y$ in the canonical variable 1, its canonical loading was 0.894 . The corresponding explanatory variables were GDP and RS (the canonical loadings are 0.818 and 0.797 ) in the variable set $X$. It indicates that the growth of GDP and the increase of fiscal revenue were the main driving forces of LL expansion in WHETC. Secondly, we extracted the changes variable of EL from the variable set $Y$ in the canonical variable 2 , the canonical loading was -0.634 . The corresponding explanatory variable was primary industry, its canonical loading was 0.620 . The development of agriculture was the main driving force for the reduction of EL in WHETC. 
Table 5. Canonical loading of ecological-living-production land changes. EPL: eco-production land; EL: ecological land; LL: living land; PEL: production-eco land; PLL: production-living land; PL: production land; UR: urbanization rate; Pop: population; PI: the primary industry output; SI: the second industry output; TI: the tertiary industry output; FAI: fixed assets investment; RS: retail sales; FR: fiscal revenue; URI: urban residents' income; RRI: rural residents' income.

\begin{tabular}{cccccc}
\hline \multirow{2}{*}{ Variables } & \multicolumn{4}{c}{ Canonical Loadings } \\
\cline { 3 - 6 } & & \multicolumn{2}{c}{ Wuhan City Circle } & Western Hubei Eco-Cultural Tourism Circle \\
\cline { 2 - 5 } Set $Y$ & $\mathbf{1}$ & $\mathbf{2}$ & $\mathbf{1}$ & $\mathbf{2}$ \\
\hline & EL & -0.34 & -0.295 & -0.275 & -0.534 \\
& EPL & -0.916 & 0.152 & -0.172 & 0.3 \\
& PEL & -0.629 & 0.597 & -0.648 & 0.205 \\
& LL & 0.807 & -0.29 & 0.894 & -0.109 \\
& PLL & 0.556 & -0.514 & 0.306 & 0.195 \\
& PLL & -0.293 & -0.109 & -0.058 & -0.159 \\
\hline \multirow{6}{*}{ Set $X$} & GDP & 0.906 & 0.033 & 0.818 & 0.041 \\
& Pop & 0.812 & -0.067 & 0.519 & -0.053 \\
& UR & -0.096 & 0.099 & -0.413 & 0.102 \\
& PI & 0.034 & 0.561 & 0.426 & -0.194 \\
& SI & -0.04 & -0.505 & -0.028 & -0.017 \\
& TI & 0.133 & 0.192 & -0.301 & 0.082 \\
& FAI & 0.926 & -0.058 & 0.63 & -0.032 \\
& FR & 0.872 & 0.073 & 0.654 & -0.069 \\
& RS & 0.867 & 0.161 & 0.797 & -0.042 \\
& URI & 0.647 & -0.212 & 0.282 & -0.223 \\
\hline
\end{tabular}

\section{Discussion}

\subsection{The Construction of Ecological Civilization}

Since the 18th National Congress of the Communist Party of China, China has accelerated the construction of ecological civilization and taken the optimization of spatial development pattern as the primary measure of ecological civilization construction [36]. The requirement of ecological civilization construction for the spatial optimization of ELPL is that "the land for production is used intensively and efficiently; the living land is livable and proper in size; the ecological land is unspoiled and beautiful" [5]. Hubei is a province rich in forest and water resources, enjoying a superior eco-environment in China, with mainly land with ecological function. However, the land with ecological function (EL, EPL and PEL) in Hubei Province decreased significantly from 2009 to 2014, especially in WHETC where the ecological land is superior. The decrease of the land with ecological function implies the deterioration of land ecological function in Hubei Province. Meanwhile, the land with living and production function (LL, PLL and PL) increased by 15,462.99 ha, with an increase rate of $10.96 \%$. The rapid expansion of living and production land might lead to extensive and inefficient land use. In order to realize the requirement of ecological civilization construction for ELPL, some measures for spatial development need to be taken (e.g., setting red lines for ecological protection, urban expansion and basic farmland protection for spatial development, and strictly following the red line control strategy to prevent over-expansion of living and production land and protecting the ecological function of the land, and optimizing the spatial pattern of ELPL, and constructing an ecological civilization).

\subsection{Impacts of ELPL Changes on Sustainable Development}

Regional sustainable development involves the sustainability of regional resources, environment and socio-economy [48]. Based on the results of driving force analysis of ELPL change, the Sustainable 
Development Goals (e.g., economic growth and urbanization) have synergetic or trade-off relationship with the ELPL change. The trade-offs directly affect the status of regional eco-environment and food production, which constitute obstacles in achieving the SDGs, need to be negotiated and made structurally nonobstructive by deep changes in the current strategies [46].

With the economic development and urbanization, a large amount of PEL in Hubei Province was occupied by LL and PLL. From 2009 to 2014, the PEL (e.g., arid land, paddy field) reduced by 7106.34 ha with an average annual decrease of 1421.27 ha. Especially in the areas with gentle slope and sunny-side, where the natural conditions for agricultural production are better, the number of PEL lost significantly more than the PEL gained. This trend of PEL change is detrimental to food production, and seriously threatens regional food security and sustainable development.

The important ecological projects in Hubei Province, such as the Three Gorges Reservoir and South-to-North Water Transfer Project, which makes the ecosystem security of Hubei Province of great significance to China [49]. The land with the ecological function (e.g., EL, EPL and PEL) accounted for $92.41 \%$ of the total area of Hubei Province in 2014, especially the EL was the largest of ELPL. However, the EL is seriously threatened by the largest lost land from 2009 to 2014 in Hubei Province. The agricultural production and construction land expansion occupied a large amount of EL. This phenomenon was more serious in WHETC where eco-environmental protection was much important. The changes of ELPL has caused the degeneration of the land ecological function. If the current ELPL use pattern remains unchanged, it will pose a serious threat to the sustainability of regional ecosystems.

\subsection{Ecological Preservation on Agricultural or Living Land}

Socio-economic development and human production and living activities will inevitably lead to the expansion of production land and living land [50]. From the changes of ELPL in Hubei Province, the decrease of ecological land was mainly occupied by the land for agricultural production and living. The agricultural land and living land also have a certain ecological function. Multifunctional land use and efficient ecological preservation measures on agricultural and living land can largely safeguard the regional ecological security and reduce the ecological damage caused by ELPL changes. We suggest the following measures: (1) The expansion of agricultural and living land should occupy wasteland and abandoned land with low ecological value instead of forest and water areas. (2) Greater value should be attached to the ecological function of living land. For example, developing underground living space and retaining the ecological landscape coverage, improves the greening of residential areas and creates an ecological livable environment. (3) To alleviate water and soil loss, developing the slopes into agricultural land should be prohibited. This enables the forest and grassland restored in a systematic and planned way.

\subsection{Limitations}

Land is the combination of ecological, living and production functions, and has certain subordinate functional value as well as its dominant function. The ELCS established by reclassified method in this paper only considered the dominant function of land, and other functions and land use information should also be concerned as they may have some policy implications for spatial optimization. The future ELCS should adopt specific evaluation methods to quantify the products or services provided by land and analysis the impacts of land use change on the values of land's ecological, living and production functions.

\section{Conclusions}

Rapid industrialization, urbanization and economic development exert a significant influence on the spatial pattern of ELPL in Hubei Province. This paper has established a flexible and practical ELCS, and analyzed the ELPL spatial distribution pattern, changes and the driving factors. The results 
of this study provide valuable information for the spatial pattern optimization of ELPL and planning decision making. The research results are concluded as below.

(1) The ecological function covered the largest land area among land with multi-functions in Hubei Province. EL and PEL took up the top two largest proportion of land in Hubei Province. EL was the largest in the WHETC and the PEL was the largest in the WUC; (2) The land with ecological function (e.g., EL, EPL and PEL) decreased significantly and occupied by the expansion of LL, PLL and PL. The ecological function of land was weakened, threatening the ecological security. The changes of ELPL were more intense in the economically developed WUC than in WHETC; (3) A large amount of land with ecological function was occupied by the land with living and production function in the areas with better natural conditions, which has adverse effects on ecological and food security. The growth of population, the increase of GDP, investment, and residents' income were the main driving forces of ELPL change, and agricultural development led to the decrease of EL in WHETC.

Acknowledgments: This research was financially supported by the National Key Research and Development Program (Grant No. 2017YFB0503601).

Author Contributions: Enxiang Cai and Ying Jing conceived and designed the experiments; Enxiang Cai and Yaolin Liu performed the experiments; Yaolin Liu and Chaohui Yin helped the data analysis; Yuan Gao and Junqing Wei helped the language correction; Enxiang Cai and Ying Jing wrote the paper.

Conflicts of Interest: The authors declare no conflict of interest.

\section{References}

1. Costanza, R. Ecosystem health and ecological engineering. Ecol. Eng. 2012, 45, 24-29. [CrossRef]

2. Wang, W.; Han, T. Planning of Land Use; China Agriculture Press: Beijing, China, 2002.

3. Verstegen, J.A.; Karssenberg, D.; van der Hilst, F.; Faaij, A.P.C. Detecting systemic change in a land use system by Bayesian data assimilation. Environ. Model. Softw. 2016, 75, 424-438. [CrossRef]

4. Bach, P.M.; Staalesen, S.; McCarthy, D.T.; Deletic, A. Revisiting land use classification and spatial aggregation for modelling integrated urban water systems. Landsc. Urban Plan. 2015, 143, 43-55. [CrossRef]

5. Zhang, H.Q.; Xu, E.Q.; Zhu, H.Y. An ecological-living-industrial land classification system and its spatial distribution in China. Resour. Sci. 2015, 37, 1332-1338.

6. Pérez-Soba, M.; Petit, S.; Jones, L.; Bertrand, N.; Briquel, V.; Omodei-Zorini, L.; Contini, C.; Helming, K.; Farrington, J.H.; Mossello, M.T. Land Use Functions-A Multifunctionality Approach to Assess the Impact of Land Use Changes on Land Use Sustainability; Springer: Berlin/Heidelberg, Germany, 2008.

7. Liu, C.; Xu, Y.; Sun, P.; Liu, J. Progress and prospects of multi-functionality of land use research. Prog. Geogr. 2016, 35, 1087-1099.

8. Peng, J.; Liu, Y.; Liu, Z.; Yang, Y. Mapping spatial non-stationarity of human-natural factors associated with agricultural landscape multifunctionality in Beijing-Tianjin-Hebei region, China. Agric. Ecosyst. Environ. 2017, 246, 221-233. [CrossRef]

9. Wiggering, H.; Dalchow, C.; Glemnitz, M.; Helming, K.; Muller, K.; Schultz, A.; Stachow, U.; Zander, P. Indicators for multifunctional land use-Linking socio-economic requirements with landscape potentials. Ecol. Indic. 2006, 6, 238-249. [CrossRef]

10. Barthelemy, D.; Nieddu, M. Non-trade concerns in agricultural and environmental economics: How J.R. Commons and Karl Polanyi can help us. J. Econ. Issues 2007, 41, 519-527. [CrossRef]

11. Paracchini, M.L.; Pacini, C.; Jones, M.L.M.; Perez-Soba, M. An aggregation framework to link indicators associated with multifunctional land use to the stakeholder evaluation of policy options. Ecol. Indic. 2011, 11, 71-80. [CrossRef]

12. Helming, K.; Tscherning, K.; König, B.; Sieber, S.; Wiggering, H.; Kuhlman, T.; Wascher, D.; Perez-Soba, M.; Smeets, P.; Tabbush, P. Exante Impact Assessment of Land Use Changes in European Regions-The Sensor Approach; Springer: Berlin/Heidelberg, Germany, 2008.

13. Call-Concha, D.; Denich, M. A participatory framework to assess multifunctional land-use systems with multicriteria and multivariate analyses: A case study on agrobiodiversity of agroforestry systems in Tomé Açú, Brazil. Chang. Adapt. Soc. Ecol. Syst. 2014, 1, 40-50. [CrossRef] 
14. Munda, G. Social multi-criteria evaluation: Methodological foundations and operational consequences. Eur. J. Oper. Res. 2004, 158, 662-677. [CrossRef]

15. Ministry of Land and Resource of China. The Outline of the National General Land-Use Planning (2006-2020). Available online: http:/ / www.mlr.gov.cn/xwdt/jrxw/200810/t20081024_111040.htm (accessed on 14 June 2017).

16. The State Council of the People's Republic China. The National Main Functional Areas Planning. Available online: http:/ / www.gov.cn/_zwgk/2011-06/08/content_1879180.htm (accessed on 27 September 2017).

17. Huang, J.; Zhu, L.; Deng, X. Regional differences of China's construction land expansion and its influencing factors. Sci. China Ser. D Earth 2007, 37, 1235-1241. (In Chinese)

18. Tan, M.; Lu, C. Urban land expansion and farmland loss in China. J. Nat. Resour. 2005, 20, 52-58.

19. Pradhan, P.; Lüdeke, M.K.B.; Reusser, D.E.; Kropp, J.P. Food Self-Sufficiency across Scales: How Local Can We Go? Environ. Sci. Technol. 2014, 48, 9463-9470. [CrossRef] [PubMed]

20. Jin, G.; Li, Z.; Wang, Z.; Chu, X.; Li, Z. Impact of land-use induced changes on agricultural productivity in the Huang-Huai-Hai River Basin. Phys. Chem. Earth 2015, 79-82, 86-92. [CrossRef]

21. Zeqiang, F.; Yunlong, C.; Youxiao, Y.; Erfu, D. Research on the relationship of cultivated land change and food security in China. J. Nat. Resour. 2001, 16, 313-319.

22. Jin, G.; Wang, P.; Zhao, T.; Bai, Y.; Zhao, C.; Chen, D. Reviews on land use change induced effects on regional hydrological ecosystem services for integrated water resources management. Phys. Chem. Earth Parts A/B/C 2015, 89-90, 33-39. [CrossRef]

23. Liu, C.; Liu, J. Influences of grain for green project on food security in china. J. Beijing For. Univ. 2007, 6, 42-47.

24. Nelson, E.; Mendoza, G.; Regetz, J.; Polasky, S.; Tallis, H.; Cameron, D.R.; Chan, K.M.A.; Daily, G.C.; Goldstein, J.; Kareiva, P.M.; et al. Modeling multiple ecosystem services, biodiversity conservation, commodity production, and tradeoffs at landscape scales. Front. Ecol. Environ. 2009, 7, 4-11. [CrossRef]

25. Nelson, E.; Sander, H.; Hawthorne, P.; Conte, M.; Ennaanay, D.; Wolny, S.; Manson, S.; Polasky, S. Projecting global land-use change and its effect on ecosystem service provision and biodiversity with simple models. PLoS ONE 2010, 5. [CrossRef] [PubMed]

26. Cao, S.; Lv, Y.; Zheng, H.; Wang, X. Challenges facing China's unbalanced urbanization strategy. Land. Use Policy 2014, 39, 412-415. [CrossRef]

27. Bai, X.; Shi, P.; Liu, Y. Realizing China's urban dream. Nature 2014, 509, 158-160. [CrossRef] [PubMed]

28. Steinhaeusser, R.; Siebert, R.; Steinfuehrer, A.; Hellmich, M. National and regional land-use conflicts in Germany from the perspective of stakeholders. Land. Use Policy 2015, 49, 183-194. [CrossRef]

29. Zhou, D.; Xu, J.; Lin, Z. Conflict or coordination? Assessing land use multi-functionalization using production-living-ecology analysis. Sci. Total Environ. 2017, 577, 136-147. [CrossRef] [PubMed]

30. Qu, W. Study on German regional planning. China Land. Sci. 2004, 18, 58-64.

31. Batten, D.F. Network cities: Creative urban agglomerations for the 21st century. Urban. Stud. 1995, 32, $313-327$. [CrossRef]

32. Merlin, P.; Choay, F. Dictionnaire de L'urbanisme et de L'aménagement; Presses Universitaites de France: Paris, France, 2010.

33. Dang, L.; Xu, Y.; Gao, Y. Assessment method of functional land use classification and spatial system: A case study of Yangou Watershed. Res. Soil Water Conserv. 2014, 21, 193-197.

34. Jing, C.; Peijun, S. Discussion on functional land use classification system. J. Beijing Norm. Univ. 2005, 41, 536-540.

35. Jian, X.; Yinkang, Z.; Xiaobin, J. Discussing virgin land classification subsystem based on the protection of the eco-environment. Resour. Sci. 2007, 29, 137-141.

36. Gu, S.; Hu, Y.; Zhou, H. Ecological civilization construction: Scientific connotation and basic paths. Resour. Sci. 2013, 35, 2-13.

37. Zha, X.; Huang, S.; Chen, S. Relationship between erosion of degenerated red soil and terrain slope/aspect a GIS-based research. J. Nat. Dis. 2010, 19, 32-39.

38. Dillon, W.R. Goldstein. In Multivariate Analysis: Methods and Applications; John Wiley \& Sons: New York, NY, USA, 1984.

39. Ministry of Housing and Urban-Rural Development of China. The Classification of City Land Use and Standard of Land Use Planning and Construction Land. Available online: http:/ / www.zzupb.gov.cn/data_ news/2010/9/29/516E149C-9829-4528-A337-8D68724A08B0.shtml (accessed on 17 August 2017). 
40. Ministry of Land and Resources of China. Current Land Use Classification. Available online: http:/ / www. doc88.com/p-9049335535584.htm (accessed on 17 August 2017).

41. Heilig, G.K. Anthropogenic factors in land-use change in China. Popul. Dev. Rev. 1997, 23, 139-168. [CrossRef]

42. Statistics Bureau of Hubei Province. Hubei Statistical Yearbook 2009; China Statistics Press: Wuhan, China, 2010.

43. Statistics Bureau of Hubei Province. Hubei Statistical Yearbook 2015; China Statistics Press: Wuhan, China, 2016.

44. Zhu, H.; Li, X. Discussion on the index method of regional land use change. Acta Geogr. Sin. 2003, 58, 643-650.

45. Zhou, H.; Deng, Z.; Xia, Y.; Fu, M. A new sampling method in particle filter based on Pearson correlation coefficient. Neurocomputing 2016, 216, 208-215. [CrossRef]

46. Pradhan, P.; Costa, L.; Rybski, D.; Lucht, W.; Kropp, J.P. A systematic study of sustainable development Goal (SDG) 1 interactions. Earths Future 2017. [CrossRef]

47. United Nations General Assembly. Transforming Our World: The 2030 Agenda for Sustainable Development. Available online: http://www.un.org/ga/search/view_doc.asp?symbol=A/RES/70/1\& Lang=E (accessed on 13 December 2017).

48. Tan, Y.; Xu, H.; Zhang, X. Sustainable urbanization in China: A comprehensive literature review. Cities 2016, 55, 82-93. [CrossRef]

49. Yu, G.; Feng, J.; Che, Y.; Lin, X.; Hu, L.; Yang, S. The identification and assessment of ecological risks for land consolidation based on the anticipation of ecosystem stabilization: A case study in Hubei Province, China. Land. Use Policy 2010, 27, 293-303. [CrossRef]

50. Seto, K.C.; Fragkias, M.; Gueneralp, B.; Reilly, M.K. A meta-analysis of global urban land expansion. PLoS ONE 2011, 6. [CrossRef] [PubMed]

(C) 2017 by the authors. Licensee MDPI, Basel, Switzerland. This article is an open access article distributed under the terms and conditions of the Creative Commons Attribution (CC BY) license (http:/ / creativecommons.org/licenses/by/4.0/). 